\title{
Developing English Material For Food And Beverage Service For XI Grade Students Of SMK SMSR Ubud
}

\author{
Gusti Ayu Putu Ari Utami, Nyoman Adi Jaya Putra², Dewa Putu Ramendra ${ }^{3}$ \\ 1,2,3 Universitas Pendidikan Ganesha \\ Singaraja, Indonesia \\ e-mail: ariutamiap@gmail.com; putu.ramendra@undiksha.ac.id; in_adijayaputra@undiksha.ac.id
}

\begin{abstract}
This study aimed at describing the English for Food and beverage service materials needed by students of SMK SMSR Ubud, describing how the materials were developed, and analysing the quality of the developed materials. This study used research and development model suggested by (Richey and Klein, 2007) comprising design, development and evaluation. The instruments used were questionnaires, interview guides, document analysis, and checklist. The findings of this study show that there were 7 topics needed to be developed included Preparing restaurant area, preparing and set up table, greet the guest, taking order, serving food, closing restaurant area, and non-alcoholic beverage. The materials were designed by following the English for Specific Purposes (ESP) material design suggested by Hutchinson and Waters (1987) involving input, content focus, language focus and task. Since English for food and beverage is part of ESP that is under English for Occupational Purposes, the effectiveness of the developed materials was evaluated using the criteria of good ESP materials suggested by Litz (2005), Hutchinson and Waters (2008), and Tomlinson (2009). After gaining the scores from the expert judges, the data then used the categorization of good teaching materials proposed by Nurkancana and Sunartana (2011). The quality of the developed materials was categorized as good material. Thus, it can be used as a main source for learning English Food and beverage service at SMK SMSR Ubud.
\end{abstract}

Keywords: ESP, Learning Material, Food and Beverage Service

\section{Introduction}

Bali is a tourist destination which has a unique culture and society, therefore Bali is a famous island in over the world. Bali Island has developed as one of the world's premier tourist destinations with over one million foreign visitors flying directly to Bali. By those reasons may people desire to work in tourism sector. An important element in tourism industry is a human resource. The human resource factor plays a major role in promoting tourism industry. Thus, they should have good communication skills. According to Zahedpisheh, Bakar \& Saffari (2017), employees who work in tourism and hospitality industry are entirely and highly aware of the importance language proficiency and they need to have good command of English in their workplace. One of the employees working in the hotel industry is a waiter.

Working at tourism sector especially being a Waiter/waitress requires professional competence in the field of tourism. The needs of qualified and professional staff in the tourism field as well as ability to communicate English fluently and accurately must be mastered properly. One solution to cope this problem is to learn ESP (English for specific purposes) or specifically English for Food and beverage service. Food and Beverage Service covers the knowledge and skills necessary for those studying or working at a variety of levels in food and beverage service.

However, in order to develop the quality of English competence, English for food and beverage service needs to have or develop appropriate material. In addition, ESP material uses learning-centered approach to English language teaching whose methodology is based on the specific needs of the learner Hutchinson and Waters (1987), In other words, knowing the needs of the students is considered fundamental in developing English for food and beverage service materials because students come to a class with different need and social background. Without matching the needs, social background of students and current technologies to ESP material, it is impossible to create relevant materials for specific jobs. 
SMK SMSR Ubud is Tourism Vocational high school which is located at Ubud. SMK SMSR offers one major that is Hotel accommodation which has four programs study such as Food and beverage service, Food and beverage product, House Keeping, and Front office. The food and beverage service program used an old book. the book has not been revised and updated yet since it was firstly used in SMK SMSR Ubud. Another problem was the text book was not well-sequenced. As Hutchinson and Waters (1987:108) state that a well sequenced textbook material consists of input, content focus, language focus, and task.

In the process of developing teaching and learning material, the first thing to do is to analyze the needs. Nunan (1988) needs analysis refers to a family of procedures for gathering information about learners and about communication tasks. Li (2014) adds that needs analysis is an activity to gather preliminary information to develop a learning curriculum that includes learning material, teaching and learning activities, developing tests and evaluating. Hutchinson and Waters (1987:54) define learning needs as what learners need to do in order to learn. In the same vein, Robinson (1991: 7) states that learning needs are what the learner needs to do to actually acquire the language. In this sense, learning needs look for data in relation to the learning situation which take into consideration learners type, cultural awareness and proficiency level in English, the available materials, the existing resources and all the information that can help the teacher to provide the learners with the appropriate knowledge

The existence of textbooks on food and beverage service is needed to support the teaching and learning process. Therefore, this study aims to develop English teaching materials for food and beverage service. The results of this study will be in the form of books and completed by Compact disk (CD) for listening task that can be used by students at SMK SMKSR Ubud.

\section{Methods}

\section{Research Design}

In this study, the Richey and Klien model was implemented. In implementing Richey and Klein model, there are three processes namely Design, Development and Evaluation ) (Richey \& Klein, 2007). In the design process, it seeks the understanding of the needs analysis Richey \& Klein (2007). In the development process, the result of the needs analysis was used as a ground to build the product. The evaluation process was conducted in order to see the quality of the product included the strengths and weaknesses of the product and made sure that the product developed met the functionalities and requirements during the design and development phase. The procedure of $\mathrm{DnD}$ is presented as designing process, development process, and evaluation process.

During the designing process, the needs was assessed through questionnaire, document analysis and interview. This was done to identify the teaching and learning goal and the teaching and learning material. The document analysed was the syllabus used in SMK SMSR Ubud and SKKNI (National qualification framework) and the interview was conducted with students, teachers and stakeholders of SMK SMSR Ubud and also the stakeholder at Bridges Bali restaurant.

The results from the needs analysis are then used as the basis for developing the book. Each material identified will be described through several units in the book. In conducting the book development process, this research uses the theory of material development by Hutchinson and Water (1987) which consists of input, content, language focus and tasks. This process also includes organizing the layout of the book.

In determining the quality of the books developed, this study uses expert judgment. Two experts and one practitioner were asked to assess the quality of the product descriptively based on five criteria namely (1) Layout and Design, (2) Activities, (3) Skill, (4) Language Type and (5) Subject and Content.

Instrument refers to tools to collect the data (Cresswell, 2012). In this study, to collect the data, checklist, questionnaire, and interview guide were used. The development interview guide was based on theory of need analysis of ESP developed by Hutchinson and Waters (1987) and SKKNI- National Standard Working Competence. 
The results of the document analysis will be analyzed descriptively to find materials that fit the needs of student. The results of the interview will be analyzed using an interactive analysis model by Miles and Huberman in (Sugiyono, 2014) which includes data reduction, data display, conclusion drawing and verification.

\section{Results and Discussion}

\section{Result}

After conducting a document analysis, questionnaire, and interview, the needs are identified. To master knowledge and skills in a Food and beverage service, there are several materials that need to be taught to students. These materials include preparing restaurant area, preparing and set up table, greet the guest, taking and process the order, serving food and beverage, close restaurant area, non-alcoholic beverage. The result of needs analysis also identified the competencies, material and activities as shown in Table 1.

Table 1. Needs Analysis Result

\begin{tabular}{|c|c|c|c|c|}
\hline No. & Unit Title & $\begin{array}{c}\text { Basic } \\
\text { Competencies }\end{array}$ & $\begin{array}{l}\text { Indicators of } \\
\text { Achievement }\end{array}$ & Activities \\
\hline 1. & $\begin{array}{l}\text { Preparing } \\
\text { restaurant } \\
\text { area }\end{array}$ & $\begin{array}{l}\text { Adequate } \\
\text { understanding } \\
\text { of the concept } \\
\text { of preparing } \\
\text { restaurant area }\end{array}$ & $\begin{array}{l}\text { 1. Adequate knowledge } \\
\text { of the procedure in } \\
\text { preparing restaurant } \\
\text { equipment. } \\
\text { 2. Adequate knowledge } \\
\text { of polishing restaurant } \\
\text { equipment } \\
\text { 3. Adequate ability to tell } \\
\text { the language } \\
\text { expressions in } \\
\text { preparing restaurant } \\
\text { area. }\end{array}$ & $\begin{array}{l}\text { 1. Crossword activity } \\
\text { 2. Listen and complete the } \\
\text { dialogue. } \\
\text { 3. Role-play activity } \\
\text { 4. True/False activity } \\
\text { 5. Write the correct expression } \\
\text { or response in the table. }\end{array}$ \\
\hline 2. & $\begin{array}{l}\text { Preparing } \\
\text { and set up } \\
\text { the table }\end{array}$ & $\begin{array}{l}\text { Adequate } \\
\text { understanding } \\
\text { of the concept } \\
\text { preparing and } \\
\text { set up the table }\end{array}$ & $\begin{array}{l}\text { 4. Adequate knowledge } \\
\text { of the concept of table } \\
\text { set up. } \\
\text { 5. Adequate knowledge } \\
\text { of the procedure of } \\
\text { table set up. } \\
\text { 6. Adequate ability to tell } \\
\text { the language } \\
\text { expressions in setting } \\
\text { table. }\end{array}$ & $\begin{array}{l}\text { 1. Matching activity } \\
\text { 2. Listen to an audio and } \\
\text { complete the paragraph. } \\
\text { 3. Role-play activity } \\
\text { 4. Answer some questions } \\
\text { 5. Word search activity }\end{array}$ \\
\hline 3. & $\begin{array}{l}\text { Greet } \\
\text { guest }\end{array}$ & $\begin{array}{l}\text { Adequate } \\
\text { understanding } \\
\text { of the concept } \\
\text { of Greeting the } \\
\text { guest }\end{array}$ & $\begin{array}{l}\text { 7. Adequate knowledge } \\
\text { of the greeting or } \\
\text { welcoming guest } \\
\text { 8. Adequate knowledge } \\
\text { of being a good } \\
\text { waiter/waitress } \\
\text { 9. Adequate ability to tell } \\
\text { the language } \\
\text { expressions of } \\
\text { welcoming guest }\end{array}$ & $\begin{array}{l}\text { 1. Complete the pictures with } \\
\text { appropriate expression } \\
\text { 2. Listen to an audio and } \\
\text { answer the questions } \\
\text { 3. Role-play activity } \\
\text { 4. Answer some questions. } \\
\text { 5. Mind mapping }\end{array}$ \\
\hline 4. & $\begin{array}{l}\text { Taking and } \\
\text { process the } \\
\text { order }\end{array}$ & $\begin{array}{l}\text { Adequate } \\
\text { understanding } \\
\text { the concept of } \\
\text { taking order }\end{array}$ & $\begin{array}{l}\text { 1. Adequate knowledge } \\
\text { of taking order } \\
\text { 2. Adequate knowledge } \\
\text { the procedure in taking } \\
\text { order } \\
\text { 3. Adequate ability to tell } \\
\text { the language } \\
\text { expressions of taking } \\
\text { order }\end{array}$ & $\begin{array}{l}\text { 1. Write some items to go in } \\
\text { each category beginning } \\
\text { with the set letter. } \\
\text { 2. Listen to a short dialogue } \\
\text { and complete the } \\
\text { conversation. } \\
\text { 3. Role-play activity } \\
\text { 4. List of the procedure in } \\
\text { taking order by reread the } \\
\text { article. }\end{array}$ \\
\hline
\end{tabular}


Indonesian Journal of Educational Research and Review, Vol 3 No 2, Tahun 2020

p-ISSN: 2621-4792, e-ISSN: 2621-8984

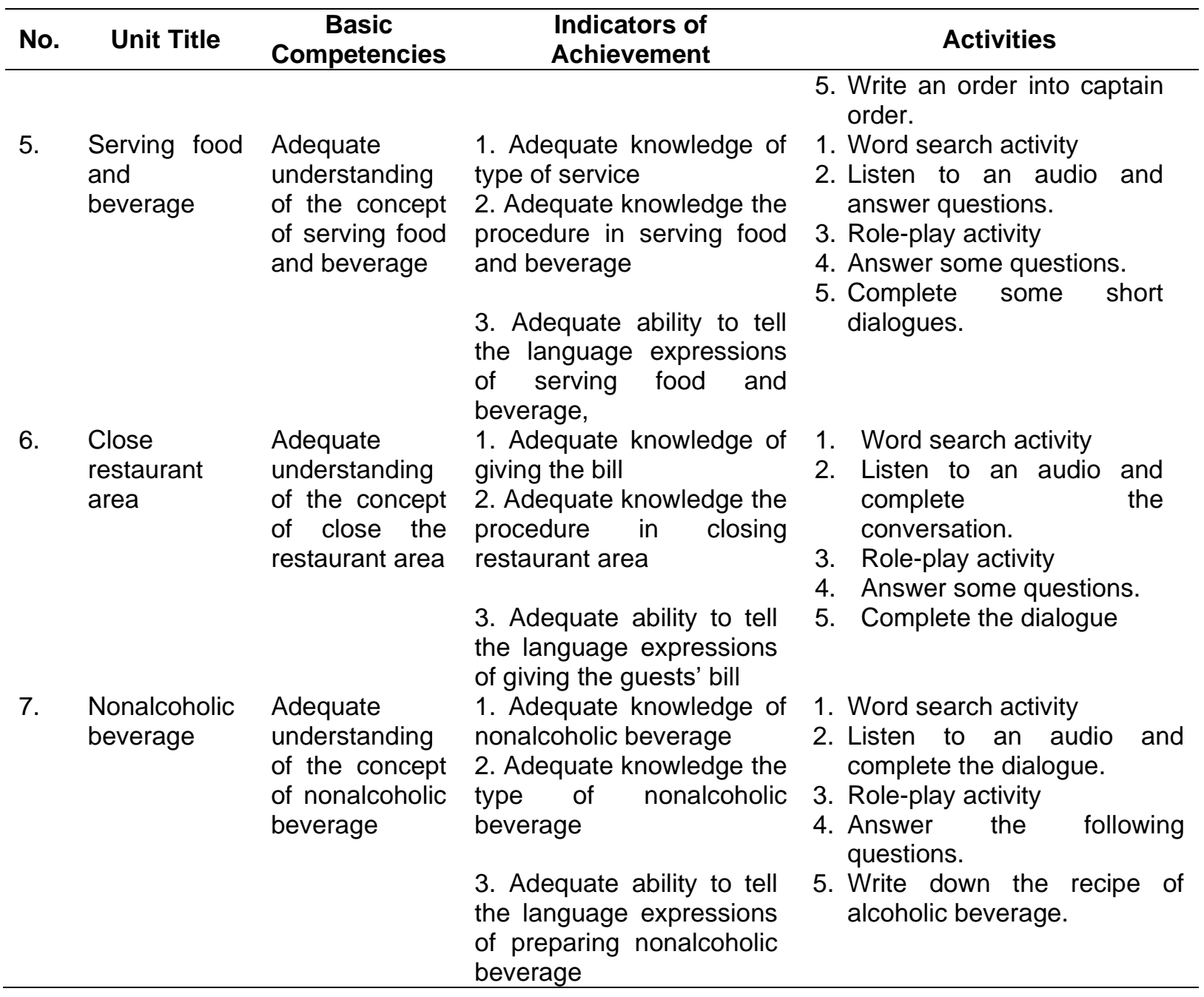

After identifying the needs, the next step is to design the book. The book design includes putting input, content, language focus and tasks as shown in Table 2.

Table 2. The Process of Developing the Book

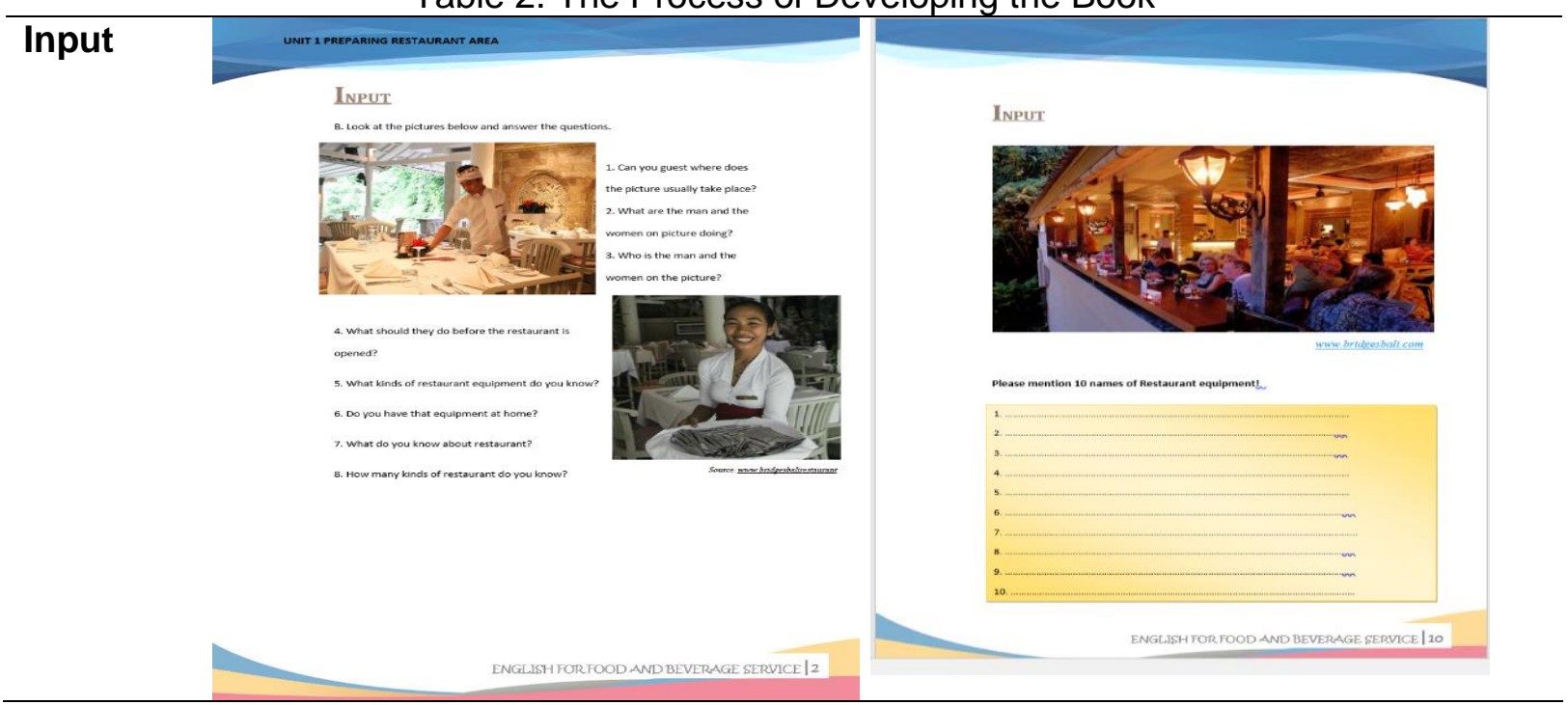


Indonesian Journal of Educational Research and Review, Vol 3 No 2, Tahun 2020

p-ISSN: 2621-4792, e-ISSN: 2621-8984

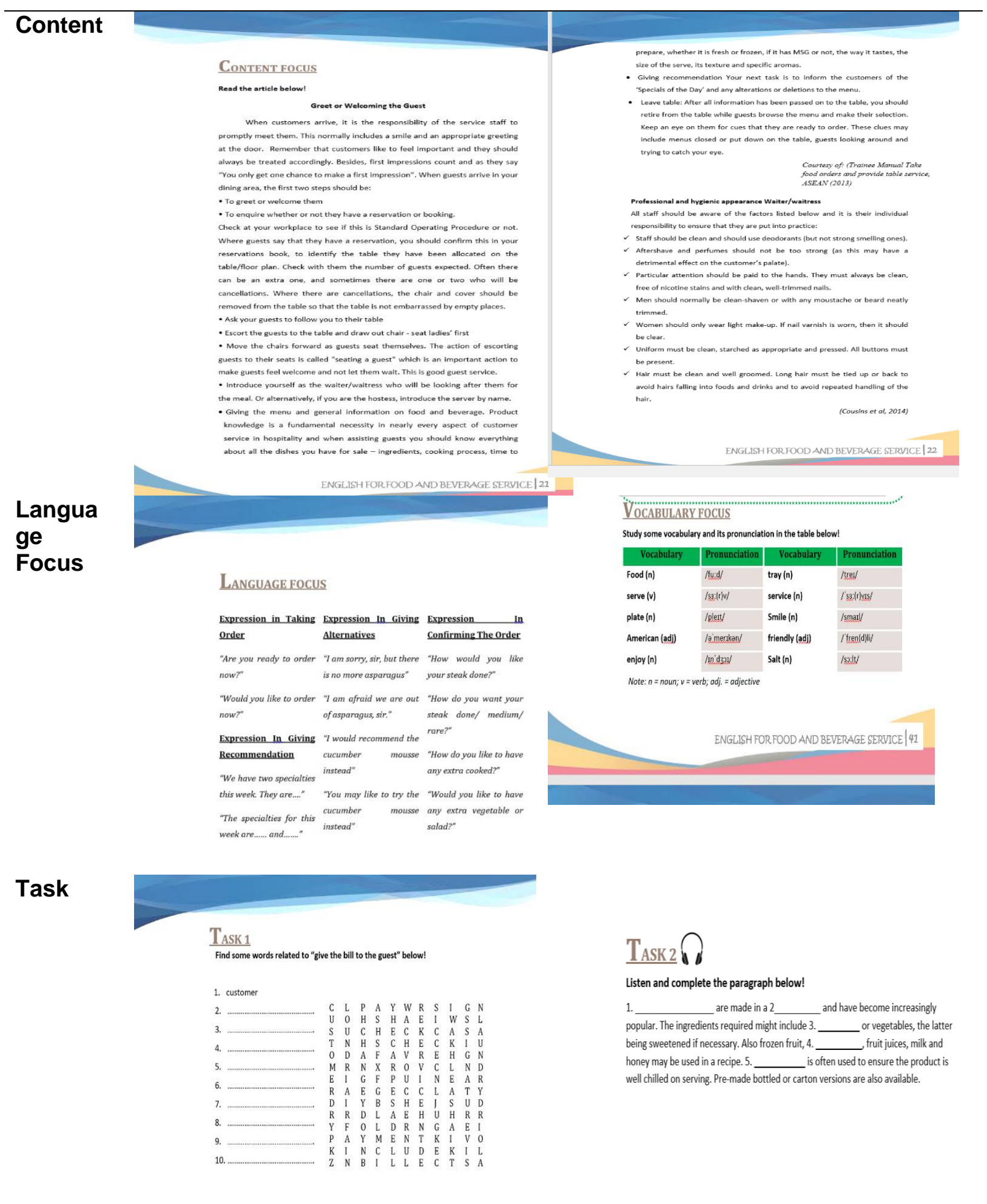

The next process conducted was evaluating the product. Based on the evaluation form, there are 25 items that should be assessed by the two expert judges and one practitioner. The maximum score for each item was 5 and the minimum score was 1 . Thus, the total of maximum score was 375 and the minimum score was 75 .

In judging the quality of the product, a set of category is developed. The product could be categorized as excellent, good, average, below average, and poor as shown in Table 3. 
Table 3. Result of the Formula Used in Analyzing the Quality of the Material Developed

\begin{tabular}{ccc}
\hline Criteria & Interval Score & Category \\
\hline $\bar{X} \geq \mathrm{M} i+1.5 \mathrm{SD} i$ & $\bar{X} \geq 337.5$ & Excellent \\
$\mathrm{M} i+0.5 \mathrm{SD} i \leq \bar{X}<\mathrm{M} i+1.5 \mathrm{SD} i$ & $262.5 \leq \bar{X}<337.5$ & Good \\
$\mathrm{M} i-0.5 \mathrm{SD} i \leq \bar{X}<\mathrm{M} i+0.5 \mathrm{SD} i$ & $187.5 \leq \bar{X}<262.5$ & Average \\
$\mathrm{M} i-1.5 \mathrm{SD} i \leq \bar{X}<\mathrm{M} i-0.5 \mathrm{SD} i$ & $112.5 \leq \bar{X}<187.5$ & Below Average \\
$\bar{X}<\mathrm{M} i-1.5 \mathrm{SD} i$ & $\bar{X}<112.5$ & Poor \\
\hline
\end{tabular}

From the evaluation given by the three experts, it was known that the total score from the first expert judges was 108. It was considered as a good material. The second expert gave 112 as the total score. It was considered as a good material as well.

\section{Discussions}

In identifying learners' needs towards the materials, needs analysis was used by the researcher. Based on the analysis, the established materials were developed. As an outcome, seven units were developed as materials for teaching English for Restaurant. Those were: preparing restaurant area, preparing and set up table, greet the guest, taking and process the order, serving food and beverage, closing restaurant area, non-alcoholic beverage.

From the results of evaluations by experts, the average results of the three experts showed that the value obtained was 334 , which falls into good category. Even though, there are some aspect was improved by the experts. Nevertheless, the contents of the book have reflected the results of the needs analysis. The contents of the book can be as a main source for learning English for Food and beverage service at SMK SMSR Ubud.

\section{Conclusion and Recomendation}

As a results of the study found that there are seven materials that need to be mastered in the food and beverage service which includes preparing restaurant area, preparing and set up table, greet the guest, taking and process the order, serving food and beverage, close restaurant area, non-alcoholic beverage. The results of the needs analysis are then developed into a textbook. The quality of the books developed is good according to the results of three expert tests. Future studies are expected to explore more deeply about the needs of food and beverage service. In addition, for further research this study can be used as a study material to improve the quality of the books developed.

\section{References}

Basturkmen, H. (2006). Ideas and Options in English for Specific Purposes. London: Lawrence Erlbaum Associates, Publishers.

Basturkmen, H. (2006). Developing courses in English for specific purposes. Springer. The Electric Journal for English as a Second Language. 16(1). 90-102

Celce-Murcia, M.. 2001. Teaching English as a Second or Foreign Language: Third Edition. USA: Heinle \& Heinle

Denok, L., Suastra, M., Pastika, W., \& Sedeng, N. (2017). Developing A Method of Learning English Speaking Skills Based on the Language Functions Used in the Food and Beverage Service. 11(1), 70-79.

Dudley-Evans, T., and St John, M.J. 1998. Developments in English for Specific Purposes: A multi-diciplinary approach. United Kingdom: Cambridge University Press.

Frendo, E. 2005. How to Teach Business English. England: Pearson Education Limited.

Huh, S. (2006). A Task-Based Need Analysis for a Business English Course. Second Language Studies , 24 (2), 1-64.

Hui Lin, C., Chih Wu, W., \& Tsuo Huang, Y. (2013). English for Specific Purposes ( ESP ) for Hospitality College Students and Hotel Employees in Taiwan Corresponding Author: Chia-Hui Lin English for Specific Purposes ( ESP) for Hospitality College Students and Hotel Employees in Taiwan. 1(8), 1-14. 
Hutchinson, T., \& Waters, A. (1987). English for Specific Purposes. United Kingdom. Cambridge University Press.

Kasumajaya, I. D. M. B., Budasi, I. G., \& Padmadewi, N. N. (2015). Developing English Materials for Front Office Course for the Students of Hotel Accommodation of PPLP Dhyana Pura. Ganesha University of Education.

Kusumoto, Y. (2008). Need Analysis: Developing a Teacher Training Program for Elementary School Homeroom Teachers in Japan. Second Language Studies , 26 (2), 1-44.

Li, J. (2014). Needs Analysis: An Effective Way in Business English Curriculum Design. Theory and Practice in Language Studies, 4(9), 1869-1874. https://doi.org/10.4304/tpls.4.9.1869-1874

Litz, D. R. (2005). Textbook Evaluation and ELT Management: A South Korean Case Study. Asian EFL Journal , 6 (4), 1-53.

Manik Puspita, N.N., Budasi, I.G., Ramendara, D.P. (2019). Developing English Learning material for Housekeeping departement PPLP Pansophia Singaraja. Ganesha University of Education.

Maya Apsari, N.L.P., Adi Jaya Putra,I.N., Lokita Purnamika Utami.,I.G.A. (2019). Developing Flash English E-Media of Food Production Materials for Culinary Students at Apollonia Hotel School. Ganesha University of Education.

Miles, M. B., \& Huberman, A. M. (2014). Qualitative Data Analysis: A Methods Sourcebook. London: SAGE Publishing.

Mohammadzadeh, S., Barati, T., \& Fatemi, M. A. (2015). An Investigation into The English Language Needs of Bank Employees of Saderat Bank In Mashhad. Theories and Practice in Language Studies , 5 (8), 1695-1702.

Nunan, D. (1988). Syllabus Design. Oxford: Oxford University Press.

Nurefendy, D. (2013). Developing English Learning Materials.

Nurkancana, W., \& Sunartana, P. (2011). Evaluasi Hasil Belajar. Surabaya: Usaha Nasional.

Putrawan, I. W. (2013). Developing English Materials for the Eleventh Grade Students of Smk Triatma Jaya Singaraja With the Insertion of the Values of Nation. 1(c).

Riasa, L., Nitiasih, P. ., \& Putra, I. N. A. . (2018). Developing English for Food and Beverage Service Course Materioals for D3 Perhotelan, Universitas Pendidikan Ganesha. Jurnal Pendidikan Bahasa Inggris Indonesia, 6(1), 1-10. https://doi.org/10.23887/jpbi.v6i1.2706

Richards, J.C., and Schmidt, R. 2002. Longman Dictionary of Language Teaching and Applied Linguistics. London: Longman

Richey, R., \& Klein, J. (2014). Design and Development Research. In M. Spector, D. Merrill, J. Elen \& M. Bishop, Handbook of Research on Educational Communications and Technology (4th ed., pp. 141-150). London: Springer.

Robinson, P.C. 1991. ESP Today: A Practitioner Guide. Great Britain: Prentice Hall

Rosyidin, I., \& Ariana, S. (2014). Developing Students' Speaking Competence in "Food and Beverage Subject" in Palembang Iskandar. International Proceedings of Economics Development and Research, 77.9. https://doi.org/10.7763/IPEDR. 2014. V77. 9

Saragih, E. (2014). Designing ESP Materials for Nursing Students Based on Need Analysis. International Journal of Linguistics , 6 (4), 59-70.

Suryani, L., Putra, I. N. ., \& Artini, L. . (2019). Developing English Supplementary Local Wisdom-Based Listening Materials Using Natural Reader 14 Application. Lingua Scientia, 26(1), 24. https://doi.org/10.23887/ls.v26i1.18845

Tomlinson, B. (2009). Materials Development in Language Teaching. Cambridge: Cambridge University Press.

Vicic, P. (2011). Preparing materials for ESP teaching. Inter Alia 2 , 107-120.

Yusnita, H. W., Yulianto, A., Gamping, A., \& Gamping, A. (2013). Upaya Food and Beverage Restaurant Dalam Meningkatkan Kepuasan Tamu Melalui Variasi Produk. Jurnal Khasanah IImu, IV(1), 67-81. https://doi.org/10.1109/CEIDP.1988.26361 
Zeng, R. (2013, July). Compiling Principles and Standards of ESP Course Books-Taking English Course Books of Textile Foreign Trade as an Example. In 2nd International Conference on Science and Social Research (ICSSR 2013). Atlantis Press. 347-350.

Zahedpisheh, N., Bakar, Z. B., \& Saffari, N. (2017). English for Tourism and Hospitality Purposes (ETP). English Language Teaching , 10 (9), 86-94. 